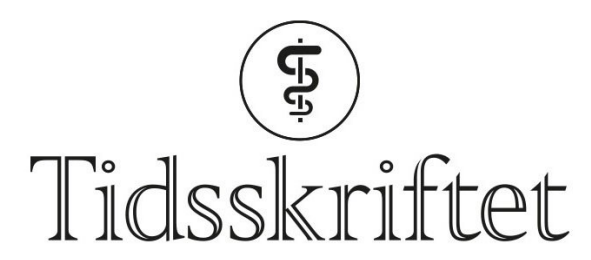

DEN NORSKE LEGEFORENING

\title{
Ord ut og ord inn
}

FRA REDAKTØREN

\section{STIG ROGNES}

E-post: stig.rognes@tidsskriftet.no

Stig Rognes er master i lingvistikk og manusredaktør i Tidsskriftet.

\section{MARIT FJELLHAUG BEEN}

Marit Fjellhaug Been er cand.philol. i nordisk språk og litteratur og er manusredaktør i Tidsskriftet.

Vi har fjernet allmennordene fra Tidsskriftets ordliste og ber nå isteden forfatterne om å følge gjeldende offisiell rettskriving. I praksis betyr det større valgfrihet og rom for individuell språkstil.

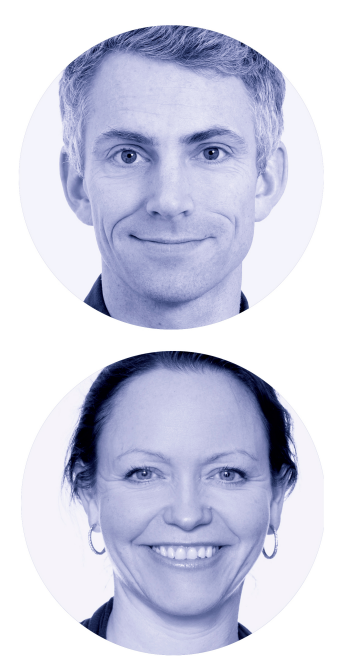

Foto: Sturlason

Tidsskriftet må ha et godt fungerende norsk medisinsk fagspråk for å få formidlet innholdet. Et av verktøyene er Tidsskriftets ordliste med «anbefalte skrivemåter for medisinske ord og uttrykk» (1), som siden utgivelsen i 1973 er blitt revidert og justert flerfoldige ganger. I dag inneholder den drøyt 3 ooo oppføringer. De fleste er fagtermer, men lista har inntil nylig også rommet en del helt vanlige allmennord. Disse ordene har vært basert på ulike språknormer, redaktørers preferanser og samfunnspolitiske føringer. Til tider har dette skapt stilmessig forvirring, idet former som bein og sju ble brukt samtidig som frem og solen. Husnormen de siste årene har fulgt et moderat bokmål. Det har vært lite rom for variasjon: Ben, boken, deltager, endrede, frem, solen, syv og trett var tillatt, men ikke bein, boka, deltaker, endrete/endra, fram, sola, sju eller trøtt.

Disse språklige føringene har skapt misnøye hos enkelte av våre artikkelforfattere. Mange føler seg ikke hjemme i en slik «språklig tvangstrøye» (2) og blir frustrerte over å få rettet 
ordformer som er naturlige for dem. Ikke så rart, all den tid formene er i tråd med den offisielle bokmålsnormen. Ofte sitter disse formene som ikke har vært tillatt i Tidsskriftet, i ryggmargen hos både forfattere og redaktører, og sannsynligvis også hos et flertall av befolkningen. Med Nasjonalbibliotekets søketjeneste NB N-gram finner man at de konkurrerende skrivemåtene som regel er like frekvente, og i noen tilfeller er de "forbudte» formene mest brukt. Da oppleves husnormen som for streng.

Nå er det ikke nødvendigvis et mål å følge flertallet. Tidsskriftet har en klar målsetting om «å speile mangfoldet i medisinen og blant forfattere, for eksempel med hensyn til ulike kjønn, bosted, etnisitet og hvor man er i karrieren» (3). En naturlig konsekvens av dette vil være å også speile det språklige mangfoldet og å ta i bruk hele bokmålsnormen og tillate alle tillatte former. Dagens norm gir stor valgfrihet og legger til rette for et talemålsnært skriftspråk for de som ønsker det.

Som en del av det nasjonalbibliotekar Aslak Sira Myhre i Dagsavisen kalte «den kompakte majoriteten, alle de uformelle normererne av språk i det daglige, aviser, lærere, forfattere og skribenter som gjennom sine valg gjør mine valg stadig vanskeligere å holde fast på» (4), har vi i redaksjonen valgt å gå bort fra en snever husnorm. Vi ønsker ikke å bidra til å opprettholde oppfatningen om a-endinger og diftonger som uakademiske (5). Nylig fjernet vi derfor om lag 400 allmennord fra ordlista vår og erstattet dem med én regel (6): «På norsk står du fritt i valg av skriftspråksvariant så lenge du følger offisiell rettskriving for enten bokmål eller nynorsk.»

Det er Språkrådet som utarbeider bokmåls- og nynorsknormen og dermed avgjør hva som er gjeldende rettskriving. Godkjente skrivemåter finner man i Bokmålsordboka og Nynorskordboka (ordbok.uib.no), som drives av Universitetet i Bergen og Språkrådet. Disse er gratis og «dei einaste fritt tilgjengelege digitale ordbøkene som gjer greie for heile breidda av former» (7). Der finner man dessuten bøyingsskjema for alle oppslagsordene. Står det der, er det lov - også i Tidsskriftet. Ordbøkene oppdateres kontinuerlig, og det pågående revisjonsprosjektet vil sørge for at også ordtilfanget, definisjonene og brukseksemplene følger dagens språkbruk (7).

Vi ønsker ikke å bidra til å opprettholde oppfatningen om a-endinger og diftonger som uakademiske

Om noen nå skulle være bekymret for en nært forestående flom av radikalt bokmål i Tidsskriftets spalter, vil ikke det i prinsippet være noe nytt. Det er snart hundre år siden G. Winge i forargelse over å ha lest ordet søknad, og ikke ansøkning, «i al sømmelighets og fornufts navn» ba om at språket i Tidsskriftet måtte holdes "purt og rent» (8). Men vi vil heller slutte oss til lingvisten Marit Julien: «Ettersom talespråket er i konstant endring, kan ein ikkje ha tradisjonen som einaste rettesnor dersom ein vil ha eit skriftspråk som skal kunna brukast av alle» (9). For det må jo være målet.

\section{LITTERATUR:}

1. Tidsskrift for Den norske legeforening. Ordliste. https://tidsskriftet.no/annet/ordliste Lest 19.8.2019.

2. Størdal K. Tidsskriftets språkpoliti(kk). Tidsskr Nor Legeforen 2010; 130: 524. [CrossRef]

3. Slagstad K. Demokratiet dør i skyggene. Tidsskr Nor Legeforen 2019; 139. doi: 10.4045/tidsskr.19.0193. [PubMed][CrossRef]

4. Myhre AS. Å stjele et språk. Dagsavisen 12.5.2017. https://www.dagsavisen.no/debatt/a-stjele-et-sprak-1.965820 Lest 19.8.2019.

5. Kjelaas I. De sier vulgært, jeg sier talemålsnært. Forskerforum 19.6.2017. https://www.forskerforum.no/de-sier-vulgaert-jeg-sier-talemalsnaert/ Lest 19.8.2019.

6. Tidsskrift for Den norske legeforening. Forfatterveiledning. Språk. https://tidsskriftet.no/annet/sprak Lest 19.8.2019. 
7. Institutt for lingvistiske, litterære og estetiske studier, Universitetet i Bergen. Revisjonsprosjektet. https://www.uib.no/lle/revisjonsprosjektet Lest 14.8.2019.

8. Winge G. Sproget i «Tidsskriftet». Tidsskr Nor Lægeforen 1925; 45: 95-6. Gjengitt på https://tidsskriftet.no/2005/o2/tidligere-i-tidsskriftet/det-norskeste-norske-sprakdebatt Lest 19.8.2019.

9. Julien M. Om språk og normer. Syn og segn 2017;3.

https://www.synogsegn.no/artiklar/2017/utg\%C3\%A5ve-3-17/marit-julien/ Lest 20.8.2019.

Publisert: 9. september 2019. Tidsskr Nor Legeforen. DOI: 10.4045/tidsskr.19.0540

(C) Tidsskrift for Den norske legeforening 2020. Lastet ned fra tidsskriftet.no 